\title{
Reflexões Biogeográficas acerca da origem, hipóteses, dispersão e distribuição dos Sars-CoV-2 (Corona Vírus)
}

\author{
Biogeographic reflections on the origin, hypotheses, dispersion and \\ distribution of Sars-Cov-2 (Corona Virus)
}

Karine Bueno Vargas'; Sarah Lawall"

\section{RESUMO}

A presença dos vírus no Planeta Terra é anterior a nossa existência. Vírus são seres parasitas, e sua sobrevivência depende de outro ser vivo, como também sua dispersão só ocorre mediante a circulação do hospedeiro. A Biogeografia é a ciência que estuda a distribuição dos seres vivos, no entanto, raros são os estudos que vinculam esta ciência com a dinâmica de difusão destes microrganismos. O presente artigo objetiva-se estabelecer reflexões biogeográficas no contexto dos vírus e sua distribuição pela superfície terrestre, dando enfoque a pandemia do Sars-Cov-2, a fim de avançar as discussões para uma possível "Biogeografia dos Vírus". A partir do método analítico descritivo, três fases de disseminação viral do Sars-Cov-2 são discutidas, abrangendo a origem, dispersão e distribuição global, no período de dezembro de 2019 a maio de 2020. Primeira fase, Centro de Origem na China Continental com dispersão progressiva viral na Ásia. Segunda fase, dada a rede de fluxos globais (aviação), ocorre a geração de epicentros na Europa Ocidental e EUA, com ampla dispersão viral, iniciando a globalização do vírus. Terceira fase, caráter pandêmico com distribuição global, controle interno da China e dispersão terrestre a partir dos epicentros intercontinentais, na Europa, EUA, Oriente Médio, Brasil e Rússia. A incorporação da dinâmica viral na Biogeografia reforça o papel do homem como hospedeiro, pertencente a uma biocenose, que dita padrões de distribuição espacial os quais associam a relação homem e natureza, no contexto do avanço tecnológico.

Palavras-Chaves: Biogeografia dos Vírus; Pandemia; Dispersão; Distribuição Geográfica; Patógenos

\begin{abstract}
The presence of virus on Planet Earth precedes our existence. Virus are parasitic beings, and their survival depends on another living creature, as well as their dispersion only occurs through the circulation of a host. Biogeography is the science that studies the distribution of living beings, however, there are few studies that link this science with the diffusion dynamics of these microorganisms. This article objective to establish biogeographic reflections in the context of virus and their distribution over the Earth's surface, focusing on the Sars-Cov-2 pandemic, in order to advance the discussions towards a possible "Virus Biogeography'. From the descriptive analytical method, three phases of viral spread of Sars-Cov-2 are discussed, covering origin, dispersion and global distribution, from December 2019 to May 2020. First phase, Center of Origin in Mainland China with progressive viral dispersion in Asia. Second phase, given the global flows network (aviation), epicenters are formed in Western Europe and the USA, with wide viral dispersion, initiating the globalization of the virus. Third phase, pandemic character with global distribution, China's internal control and land dispersion from the intercontinental epicenters, in Europe, USA, Middle East, Brazil and Russia. The incorporation of viral dynamics in Biogeography reinforces the role of man as a host, belonging to a biocenosis, which stablishes spatial distribution patterns, associating the relationship between man and nature, in the context of technological advancement.
\end{abstract}

Keywords: Virus Biogeography, Pandemic, Dispersion, Geographic Distribution, Pathogens

Universidade Federal Rural do Rio de Janeiro - karibvargas@yahoo.com.br https://orcid.org/0000-0001-7998-8522

" Universidade Federal Rural do Rio de Janeiro. sarahgeoprof@gmail.com. https://orcid.org/0000-0002-0583-101X 


\section{INTRODUÇÃO}

Os vírus correspondem a microrganismos morfologicamente semelhantes às bactérias, que se distinguem genética e bioquimicamente, como também dos eucariontes, se enquadrando no domínio dos seres vivos denominado Archaea, por não possuir núcleo celular completo e nem se auto reproduzir. Os vírus enquadram-se como parasitas intracelulares obrigatórios, já que estes necessitam de um hospedeiro, a fim de adquirir elementos necessários para sua reprodução e sua dispersão irá depender da circulação do hospedeiro.

Discutir microrganismos, principalmente vírus e bactérias sob o olhar da biogeografia, possibilita inúmeras hipóteses a serem investigadas, diante o elevado potencial de dispersão e distribuição que os envolvem, pois estes apresentam padrões e comportamentos distintos, sendo responsáveis por inúmeras epidemias e pandemias ao longo da história evolutiva. A Biogeografia é a ciência que integra a vida e o espaço (Marques Neto, 2018), tendo como principal objetivo entender a distribuição espacial dos seres vivos no planeta. Neste sentido, caberia a Biogeografia o estudo de microrganismos, como os vírus?

De acordo com Freitas Junior (2011) desde os séculos XVIII e XIX, os biogeógrafos têm percorrido o mundo em busca da compreensão pela configuração e distribuição dos seres vivos pelo Planeta Terra, em escala geológica e ecológica de tempo, a fim de identificar padrões e dividir o espaço terrestre em diversas unidades espaciais bióticas. A Biogeografia em um de seus conceitos clássicos, definido por Brown e Lomolino, (2006, p. 3), considera-a como uma "ciência que se preocupa em documentar e compreender modelos espaciais de biodiversidade, sendo o estudo da distribuição de organismos, tanto no passado quanto no presente, e dos padrões de variação ocorridos na terra, relacionados a quantidade e aos tipos de seres vivos". Diante o objeto de estudo da Biogeografia ser os seres vivos, percebe-se uma imensa área de atuação para os estudos de microrganismos, já que muitos desses seres microscópicos ainda não foram identificados e estudados, e há uma ampla ocorrência em todo o planeta. Embora muitos 
pesquisadores no passado foram resistentes a concepção dos vírus como um ser vivo, atualmente nos deparamos com uma outra realidade, revelada pela presença massiva de vírus em todos os reinos do mundo natural, sua origem aparentemente tão antiga como a própria vida e sua importância na história natural de todos os outros organismos não podem ser descartadas (UJVARI, 2012). A análise filogenômica descobriu uma árvore da vida universal e revelou que os vírus modernos foram reduzidos a partir de várias células antigas que abrigavam genomas de RNA segmentado e coexistiam com os ancestrais das células modernas, sendo portando considerados seres vivos (NASIR; CAETANO-ANOLLÉS, 2015). Vale destacar que os vírus possuem linhagens contínuas de espécies virais, as quais reproduzem-se e evoluem em resposta ao ambiente, através de variabilidade e seleção, como qualquer ser vivo, e de qualquer modo, só pelo fato de depender do sistema metabólico da célula do hospedeiro, reflete a dependência de interação com os outros seres vivos (SALZANO, 2012). Os microrganismos começam a ser estudados na ciência geográfica principalmente na metade século XIX por pesquisadores franceses, em sua maioria discípulos de Vidal de La Blache, entre eles Jean Brunhes e Max Sorre, vale destacar também o pesquisador Russo Yevgeny Pavlovsky. A maior parte desses pesquisadores utilizaram o raciocínio geográfico como método analítico de compreensão, a fim de compreender a distribuição e desenvolvimento das doenças provindas de vírus, bactérias e outros parasitas, bem como, sua origem (localização), distribuição, conexão e ordem espacial.

A grande contribuição de tais autores, foi em suas visões geográficas sobre as doenças de origem zoonóticas (relação homem x animal), numa forma integradora entre Geografia Física e a Geografia Humana, ou seja, uma visão geossistêmica entre as relações natureza e sociedade, formulando a construção de uma ecologia humana.

Para Moreira (2003), a proposta de geografia médica criada por Max Sorre é a que melhor ilustra essa concepção ecológica de natureza, de homem e da relação homemmeio, uma geografia de fluxos com o processo biogeográfico da vida no centro, numa relação mutua entre biogeografia e sociologia, pois além de complexos relacionais, os 
fenômenos estão em permanente movimento, como um fluxo constante, à exemplo dos complexos patogênicos.

De acordo com Ferreira (1994), os complexos patogênicos analisam as relações entre o homem e o meio, e compreendem a ação da natureza sobre o homem, bem como a ação da humana modelando a natureza. Tais complexos se propõem a olhar para a epidemiologia, a qual procura compreender os processos subjacentes aos fenômenos em que analisa, reformulando-se diante os aprimoramentos da técnica e dos conceitos empregados pela geografia.

Diante o grande desenvolvimento da ciência na área da microbiologia, muitos autores consideram o século XXI como "Século do Genoma" diante as várias descobertas de rastreamento genético de microrganismos (Araújo, 2004; Idjavari, 2012; Moore, 1996). Datações microbiológicas associadas a estudos arqueológicos, antropológicos, geológicos, paleoambientais, entre outros, possibilitaram conhecer nossas rotas de circulação passadas, ou seja, nossas pegadas ancestrais até chegar à origem inicial (ponto de partida) de muitos vírus, bactérias e outros parasitas. A compreensão das rotas de circulação e sua distribuição geográfica pelo Planeta Terra, contribuíram para a compreensão da história geográfica não só dos microrganismos, mas também nos fez conhecer um pouco de nossa história evolutiva.

A proposta de um novo olhar para a Ciência Biogeográfica a partir de estudos de microrganismos, se faz mais do que nunca necessária, a qual necessita expandir sua observação tradicionalista, buscando novas abordagens, a fim de trazer grandes contribuições para as relações sociedade e natureza, como por exemplo as relacionadas à patógenos.

Discutir a abrangência do olhar biogeográfico sobre doenças, cuja origem está correlacionada a relações de contato entre espécies animais e humanas se fazem muito pertinentes, ainda mais no atual contexto. Segundo dados do monitoramento realizado pelo Centro de Pesquisas sobre o Corona vírus ligado à Universidade Jonhs Hopkins, a pandemia provocada pelo Sars-Cov-2 atingiu 185 países em apenas 3 meses de seu surto inicial, na China (JHU, 2020). Vale destacar que o padrão viral apresentado, está 
relacionado ao habitat em que o hospedeiro se encontra, ou seja, cada local da superfície terrestre de acordo com suas características socioambientais proporciona expansão ou retração viral, pelo que tem se observado. Logo, os vírus têm seu ponto de origem, ocasionado possivelmente por alterações antrópicas ao meio, e sua dispersão se dá mediante a organização da sociedade, associado ao processo de globalização viral. Sendo assim, o objetivo do presente artigo consiste na reflexão acerca dos principais conceitos da Biogeografia, como origem, dispersão e distribuição, a fim de compreender a pandemia de Sars-Cov-2, pertencente à família Coronaviridae, na tentativa de avançar a discussão para uma possível Biogeografia dos Vírus, como também de outros microrganismos. Para Kaz (2020) os vírus são uma ameaça à humanidade, mas também, em certo sentido, um elo com a nossa versão celular mais arcaica, já que no princípio, antes do verbo, nós talvez fôssemos um tipo de vírus. A metodologia para a construção desse artigo se baseou numa ampla revisão bibliográfica, a fim de construir uma abordagem analítica descritiva da "Biogeografia viral" a partir da compreensão do papel dos microrganismos na evolução do nosso Planeta. A construção da biogeografia dos vírus ancora-se nas contribuições da geografia médica, epidemiologia, ecologia e biogeografia, a fim de que essas possam subsidiar a construção do conhecimento de uma biogeografia médica, cultural e ecológica utilizando microrganismos como objeto de estudo.

Inicialmente o artigo discute os vírus, refletindo sobre suas origens e evolução, em seguida caminha para apresentação das relações sociedade-natureza e o surgimento de algumas patologias provenientes desta relação desequilibrada. Feito isso, o texto é conduzido a uma reflexão acerca da Biogeografia como conceito, objeto e diálogo com a possível Biogeografia dos Vírus e por fim, um capítulo destinado ao olhar biogeográfico para a Pandemia de Sars-Cov-2 (Covid-19).

\section{ORIGEM E EVOLUÇÃO DOS VÍRUS NO PLANETA TERRA}

A origem dos primeiros vírus no planeta terra é muito anterior ao surgimento dos primeiros hominídeos, ancestrais ao homem moderno, os quais datam sete 
milhões de anos. Há muitas teorias que levantam hipóteses sobre o surgimento dos vírus, embora inúmeras hipóteses tenham tentado explicar as origens virais, nenhuma é apoiada por dados substanciais (NASIR; CAETANO-ANOLLÉS, 2015).

Para Salzano (2012) os vírus consistem em partículas ultramicroscópicas que possuem a capacidade de entrar em outra célula e proliferar-se, porém, são incapazes de replicar-se de forma autônoma, necessitando de outro ser vivo para reproduzir-se. Segundo Ujavari (2012, p. 11), a dinâmica que envolve a propagação do vírus, ocorre da seguinte forma:

\begin{abstract}
"Todo vírus da natureza precisa do auxílio de outro ser vivo para se reproduzir. Isso ocorre porque ele é constituído apenas do seu material genético, seja DNA ou RNA. E, ao contrário das bactérias, não contém o maquinário celular necessário à sua reprodução. Por isso invade a célula de um organismo vivo (animal ou vegetal) para emprestar suas moléculas, copiar o seu próprio material genético e construir novos vírus. Sob seu comando, as células invadidas produzem cópias de seu envelope para enclausurar o seu DNA ou RNA já replicados. Formam inúmeros novos vírus iguais ao invasor. A "prole" é expulsa e está apta a repetir a operação".
\end{abstract}

A estrutura morfológica viral consiste, portanto, em um capsídeo, que é a cápsula de proteína que envolve o ácido nucleico do vírus, o qual possui um pequeno registro de material genético (DNA e/ou RNA). Como os vírus não produzem proteína por conta própria, há a necessidade de sequestrar o ribossomo de outro ser vivo, o qual possua metabolismo completo, seja bactéria, animal, planta ou humano (Homo sapiens) para que seja possível reproduzir novos capsídeos virais, ocorrentes a partir da penetração do vírus na célula de outro indivíduo, muitas vezes facilitado pela estrutura proteica que o envolve. Desse modo, podemos considerar que os vírus são parasitas, já que sua sobrevivência depende de outro ser vivo, como também sua dispersão só ocorre mediante a circulação do hospedeiro. Com relação a disseminação viral, essa ocorre por meio da expulsão do vírus do indivíduo infectado, ou seja, sendo eliminado pelo hospedeiro, por meio de secreções, relações sexuais, saliva e/ou partículas em suspensão no ar, sangue, urina e fezes, sendo essas as formas mais comuns de dispersão viral. Vale destacar, que muitas vezes o vírus ao ser 
dispersado no ambiente, acaba contaminando corpos hídricos e plantas, dos quais serão consumidos posteriormente por homem e animais, nesse processo a contaminação viral se dá por meio da ingestão.

Baltimore (1971) criou um dos sistemas de classificação viral que ainda hoje é utilizado como parâmetro na identificação do tipo viral, a qual consiste na divisão em sete tipos, baseado nas características moleculares em que cada vírus usa para armazenar sua informação genética. De acordo com autor, os vírus com DNA de fita dupla podem expressar e duplicar sua genética por processos que são idênticos aos usados pelas células. Já os vírus com outros tipos de genomas requerem sistemas especiais para replicação e transcrição, sendo possível agrupar vírus de acordo com as propriedades gerais de seus sistemas genéticos.

O RNA vírus ao ter contato com um determinado tipo de animal pode sofrer mutações, criando condições de invasão e evolução em outras espécies, sendo uma das características desse gene, o qual possui suscetibilidade de erro de cópia, replicada aos futuros descentes. Quanto maior o quantitativo de número de cópias, maior será a probabilidade de mutação, diante a troca de material genético entre os envolvidos nesse processo, podendo chegar ao surgimento de um novo tipo vírus. No entanto, as características genéticas se conservaram ao longo da história, sendo possível sequenciar os rastros evolutivos e as ancestralidades de microrganismos graças aos avanços da ciência e da genética (UJVARI, 2012).

De acordo com Ujvari (2008), o Homo sapiensjá nasceu com agentes infecciosos descentes, e alguns dos microrganismos que adquirimos em nosso organismo são resultantes do nosso passado ancestral em solo africano, como as formas iniciais do verme da Tênia, de bactérias da Tuberculose, vírus da Herpes, HPV (Papilomavírus Humano) e da AIDS (Síndrome da Imunodeficiência Adquirida), por exemplo. A partir da expansão do homem pelos continentes, os microrganismos pegaram carona, e por ser seres ubíquos, possuem capacidade de ocupar grande parte do planeta, diante a sua adaptabilidade. 
Após o domínio da agricultura e da domesticação de animais pelo homem, este deixa de ser nômade, e começa a construir seu próprio espaço territorial, tendo a possibilidade de consumir os alimentos produzidos por si mesmo, bem como aqueles produzidos por sua "comunidade". Esta nova organização espacial gerou a aglomerações sociais, como menciona Diamond (2008) que a agricultura sustenta populações humanas muito mais densas do que o estilo de vida de caçador-coletor, em média de 10 a 100 vezes mais densa.

Com o processo de dominação da natureza, acabamos também sendo dominados, pois sem enxergar os agentes infecciosos, estes utilizam nosso corpo como residência, repassando seus descentes para novas moradas, até formar um grande império viral ou bacteriológico, formando as grandes epidemias e pandemias. Diamond (2008) destaca que algumas populações de lavradores facilitaram a contaminação de novas vítimas por bactérias e vermes fecais, juntando fezes e urina e espalhando-as como fertilizante nos campos, contaminando a água, alimentos e também se auto contaminando.

O elevado avanço de doenças provindas de microrganismos ao longo da história, geraram "forças motrizes" que possibilitaram o avanço da área da microbiologia, no entanto, foi necessária a modernização da técnica para que pudéssemos compreendê-las melhor. Segundo Santos (1998) a relação entre ciência e técnica é no período atual uma relação de interdependência, a qual materializa-se no espaço constituindo o meio técnico científico-informacional, e sobre tais avanços afirma que:

Esta instantaneidade e universalidade na propagação de certas modernizações desmantela a organização do espaço anterior. Constitui, sobretudo, um fator de dispersão que se opõe de uma forma muito clara aos fatores de concentração conhecidos nos períodos anteriores (SANTOS, 1997a, p. 29).

Os microrganismos se tecnificaram junto a humanidade, numa relação mútua entre sociedade e natureza, ganhando velocidade na dispersão pelas rotas de circulação aéreas. Segundo Ujvari (2008) o termo "globalização dos microrganismos" 
ganhou importância nos últimos anos, principalmente pelo aprimoramento e popularização da aviação, em que um doente pode dar a volta ao redor do mundo em um período curto, propagando sua doença de forma rápida.

De acordo Whitman et al. (1998) e Locey e Lennon, (2016) estima-se que existam no planeta terra um trilhão de microrganismos e que apenas $0,001 \%$ foram identificados até o momento, justificando o motivo dos principais estudos serem focados em organismos patogênicos. Segundo Macfarlan et al. (2012) o DNA do nosso genoma é composto por $8 \%$ de material genético de vírus ancestrais, e a família de vírus Retroviridae é uma das grandes responsáveis por isso, diante a capacidade de inserção de material genético no DNA de seu hospedeiro, sendo este vírus da mesma família da AIDS. Ujvari (2012) estima que 40 milhões de humanos apresentem fragmentos de retrovírus, o qual teve contato com ancestrais humanos a 60 milhões de anos, sendo, portanto, registros de nossa história evolutiva. Seus traços genéticos ainda presentes, são fósseis vivos, porém estes perderam a capacidade de causar doenças, mas tiveram um papel fundamental no fortalecimento da vida na Terra.

Os retrovírus até hoje contribuem para a reprodução humana e de outros primatas, tanto na formação da placenta, como na condução da gestação, ocasionando a diminuição da defesa materna e redução do risco a rejeição do feto. Segundo Macfarlan et al. (2012), mais de 100 genes são promotores e responsáveis por dar início ao processo de transcrição embrionária, devendo esses ser ativados para ocorrer o desenvolvimento do embrião, sendo os "interruptores" que os controlam, e esses são provindos de infecções virais ancestrais, já comprovadas pela ciência. Uma das frases mais celebres frases de Louis Pasteur é “a vida não seria possível na ausência dos microrganismos", esta pode parecer contraditória em um período de pandemia, diante o grande número de mortes. No entanto, ao refletirmos sobre o papel desses seres microscópicos sobre a vida, observamos que a vida possui funcionalidades distintas ao longo do tempo, sendo cíclica, em que os microrganismos possuem várias funções. 
Os microrganismos estão em todas as fases da nossa existência, desde a fase embrionária, integrando a cadeia alimentar até a nossa decomposição, servindo posteriormente na decomposição da matéria orgânica para que novas vidas surjam. Estes seres invisíveis opticamente são, portanto, fundamentais no sistema de vida terrestre, desde a oxigenação do nosso planeta até a ciclagem de nutrientes, provedores de toda a biodiversidade, além de serem responsáveis pelo próprio controle biológico.

\section{ABORDAGENS BIOGEOGRÁFICAS PARA COMPREENSÃO DAS DINÂMICAS VIRAIS: POR QUE NÃO INCORPORAR O ESTUDO DOS VÍRUS NA BIOGEOGRAFIA?}

A Biogeografia entendida simplificadamente como a união da ciência do espaço com a ciência da vida (Marques Neto, 2018), busca compreender a distribuição da vida no planeta, associada as condições e mecanismos contidos nos diferentes espaços globais. Desde a sua sistematização no século XIX, muito impulsionada pela participação de naturalistas como Alexander Von Humboldt (pai da Fitogeografia), e uma série de conceitos foram produzidos na tentativa de definir o papel da Biogeografia como ramo da Geografia Física.

Ciência abrangente em tempo e espaço envolvendo estudos que podem tratar da história evolução do planeta à organicidade de ecossistemas micro e macro, a Biogeografia apoia-se a ciências correlatas que transcendem o campo da Geografia. De tal modo, são incorporados elementos da Biologia, Ecologia, Geologia, Paleontologia e a própria Geografia na tentativa de buscar padrões de distribuição dos seres vivos, buscando respostar para a questão geral: "por que os organismos estão onde estão"?

Assim, dentre os conceitos apreciados na literatura, Brown e Lomolino (2006) apontam que a Biogeografia é a ciência que se preocupa em documentar e compreender modelos espaciais de biodiversidade. Para além da catalogação de espécies e incluindo o papel da escala temporal, Dansereau (1957) define que ela 
estuda a origem, distribuição, adaptação e associação de plantas e animais, ou seja, distribuição dos seres vivos no espaço, através do tempo. Princípio para se pensar o próprio Darwinismo com base na evolução, seleção natural e adaptação das espécies em determinados lugares, reforçando as variáveis tempo e espaço na matriz dos estudos biogeográficos.

Conceito próximo de Dansereau (1957) é trazido por Dora Romariz (2012), a qual aponta que a Biogeografia estuda a origem, expansão e distribuição, associação e evolução dos seres vivos (plantas e animais) na superfície da Terra. Enfoque dado a superfície da Terra entendida como parte da biosfera, ou seja, palco das relações entre os seres vivos e o meio ambiente, onde eles se originam e se dispersam, buscando condições de sua adaptação, reprodução e perpetuação.

Troppmair (2012) defende que a Biogeografia estuda as interações, organizações e os processos espaciais dando ênfase aos seres vivos - vegetais e animais - que habitam determinado local: o biótopo - onde constituem biocenoses. Entende-se por biótopos o meio físico e as biocenoses, as comunidades ecológicas, ou seja, é preciso compreender a relação entre elementos abióticos e bióticos que sustentam as dinâmicas dos sistemas naturais ou seus conjuntos, os ecossistemas/geobiocenoses como proposto pelo próprio autor.

Para além do conceito, Troppmair (2012) defende que objeto da Biogeografia são os seres vivos, inclusive o homem, quando visto como participante de uma biocenose (comunidade ecológica), portanto integrante das cadeias tróficas e dependente das condições ambientais. Marques Neto (2018) defende o conceito de Troppmair pela ênfase dada do autor as organizações espaciais para explicar a dispersão e distribuição dos biótopos (substrato físico) e das biocenoses (comunidades ecológicas). De que forma a vida se organiza em diferentes biótopos? Até que ponto os biótopos influenciam a distribuição da vida na Terra interagindo nas biocenoses? Enquanto a organização natural, as interações entre as espécies e o meio natural deram base para a seleção natural, as mais adaptáveis conseguiam perpetuar-se a partir do enfrentamento e adaptação a novos ambientes e mudanças 
súbitas, como climáticas ou surgimento de barreiras geográficas, base da teoria vicariancista.

E o homem? Como ser integrante da biocenose dentro da evolução dos primatas nos últimos 65 milhões, os ancestrais do gênero Homo mantinham a preservação dos hominídeos na constante adaptação e deslocamento em busca de abrigos, alimentos e condições de reprodução dependente das condições e mudanças ambientais, que por vezes, extinguiam grupos de hominídeos (DIAMOND, 2008; FIGUEIRÓ, 2015). Porém, como aponta Figueiró (2015) pode-se considerar a espécie humana um enorme sucesso ecológico em termos evolutivos. A convivência em sociedade e o desenvolvimento da comunicação por escrita e pela fala, permitiu o desenvolvimento de sua racionalidade que foi utilizada para o domínio de ferramentas e de elementos natureza, como o fogo, que fizeram mais resistentes e adaptáveis as condições ambientais, além da domesticação de animais e plantas.

De ser biológico a ser histórico, o Homo Sapiens ou homem moderno, a partir da Revolução Industrial do século XVIII até os dias atuais, altera a dinâmica da natureza transformando em valor de uso (recurso de sobrevivência) em um valor de troca (mercadoria) como aponta Figueiró (2015). Isso engatilha o enfoque da Biogeografia Cultural, ao analisar as intervenções antrópicas e as consequências destas intervenções para os mecanismos de funcionamento e organização dos sistemas ambientais. Relação de causa e consequência que pode gerar danos, dentre eles a extinção de espécies, alterações climáticas e a disseminação de doenças, como o atual momento de Pandemia por Corona vírus, a ser tratado mais adiante.

Figueiró (2015) descreve um novo conceito para a Biogeografia, a denominando de Geografia da Biosfera, inserindo as relações do homem com o meio, destacando que para entende-la é preciso explicar a distribuição dos seres vivos na superfície da Terra, em diferentes escalas de tempo e espaço.

Considerando que os mecanismos estão relacionados tanto as variáveis físicas quanto as antropogênicas da paisagem, essa 
Geografia da Biosfera não pode prescindir dos aportes teórico e metodológico provenientes das ciências naturais e das ciências humanas (Figueiró, 2015, p.22).

As ações antrópicas influenciam a dinâmica das paisagens naturais e com isso afeta o objeto de estudo da biogeografia, que são os seres vivos. Tradicionalmente, a divisão dos grupos e correntes dentro desta ciência sempre estiveram ligadas ao estudo das vegetações (fitogeografia) e dos animais (zoogeografia), sendo menor aporte de publicações destinada ao estudo dos animais, diante o distanciamento da zoologia da grade curricular de geógrafos, não muito diferente da botânica, mas ainda a vegetação apresenta-se mais estática que os animais na paisagem, talvez seja um dos fatores que mais os aproxima dos geógrafos.

Para Romariz (2012) no contexto da paisagem é indiscutível a importância da vegetação, representando o traço mais significativo da paisagem física. Os animais ocupam um segundo plano, com relação às plantas, já que delas dependem, em grande parte, para sua alimentação e, também, não apresentam tão estreitas relações com as condições do meio. No entanto, a zoogeografia busca explicar os fatores que favorecem e/ou condicionam a distribuição dos animais na superfície terrestre, construindo hipóteses para o aparecimento, a disseminação e a extinção dessas espécies (FIGUEIRÓ, 2015).

Na concepção de Marques Neto (2018) é defendida a visão holística e não biocêntrica em prol de uma abordagem geográfica, e define a zoogeografia como o campo da Biogeografia que se incumbe dos estudos espaciais de espécies e agrupamentos faunísticos (zoocenoses) de seus aspectos históricos (evolucionários), além de suas relações com os sistemas ambientais e com as atividades humanas.

A partir disso, envolvendo a base epistemológica da ciência biogeográfica com enfoque a espécie humana, integrante de uma biocenose, ao mesmo tempo que é agente antrópico, pois, modifica e interfere na dinâmica das paisagens. Assim, podese desviar e incluir um olhar para o papel do homem na biosfera, transformando-o no habitat de inúmeros microrganismos em suas histórias evolutivas, gerando nos 
últimos 12 mil anos, as grandes epidemias e pandemias que provocaram grandes extinções.

Os vírus por diferentes concepções, inicialmente não foram considerados seres vivos, logo, não entraram na discussão dos conceitos e objetos de Biogeografia. A proximidade que invoca a relação da Biogeografia com microrganismos está na própria articulação de Romariz (2012) quando escreve sobre a Zoogeografia, a qual descreve que aparte dela pode ser destacada a sua grande contribuição para a medicina, no setor da parasitologia. O conhecimento das áreas de ocorrência de determinados insetos transmissores de doenças é de suma importância para a medicina preventiva. Trata-se de insetos transmissores e propagadores de zoonoses, ou seja, pertencente ao campo da zoogeografia, estudo do reino animal.

Em outra perspectiva, tem-se a biogeografia médica, como posta por Figueiró (2015), que se objetiva a compreender os fatores condicionantes a distribuição dos organismos vivos, os quais atuam como vetores na transmissão de doença. É importante que se faça associações entre a ecologia humana, saúde pública e Geografia Médica no trato das perspectivas da Biogeografia Médica. Ademais, a Biogeografia Cultural contribui para entendimento das ações dos homens na domesticação, alteração de estrutura de DNA de espécies, introdução de espécies, alterações nos ecossistemas, hábitos e modo de vida, além das formas tradicionais de manejo da natureza. Assim, o estudo do próprio homem como hospedeiro associado as suas ações, podem disseminar ou extinguir microrganismos, como também podem ser incorporadas nas análises da biogeografia para entender a dinâmica das epidemias/pandemias e em especial, a Sars-COV-2.

Ainda, dentre os organismos vivos que atuam como vetores na transmissão de doença, está o homem, que hospeda uma série de “micróbios" como vírus, bactérias e parasitas que estiveram presente em toda história evolutiva da terra, combinada com a migração, adaptação, evolução, reprodução e mudanças nas organizações sociais dos homens nos últimos 12 mil anos ou mais longe, 2 milhões de anos desde a evolução do primeiro hominídeo. 


\section{REFLEXÕES ACERCA DA RELAÇÃO SOCIEDADE E NATUREZA: COMO SE ORIGINAM E SE DISTRIBUEM OS VÍRUS PELO PLANETA TERRA?}

De acordo com Zlojutro et al. (2019) a origem e dispersão de doenças infecciosas e emergentes está aumentando em prevalência e escala, as quais são introduzidas naturalmente, acidentalmente ou maliciosamente. As alterações e impactos na natureza, associados a intervenções do homem ao ciclo biológico animal e as mudanças climáticas, estão entre os principais fatores de propagação de zoonoses, ou seja, doenças infecciosas que podem ser transmitidas de animais a humanos, mas também de humanos a animais. Muitos cientistas (Ujvari, 2012; Diamond, 2008; Wallace, 2016) afirmam que mais da metade de todas as doenças infecciosas da história, foram originalmente transmitidas para os seres humanos de animais domesticados ou selvagens, como mencionados alguns casos anteriormente. Contudo, no que se refere as taxas de infecções e mortes anuais, os três vírus mais perigosos ainda hoje são os da gripe, o HIV (Aids) e o HBV (hepatite) (MILLER e SPOOLMAN, 2016).

As infecções respiratórias inferiores continuam sendo uma das doenças transmissíveis mais mortais, as quais causaram 3 milhões de mortes em todo o mundo somente em 2016 (WHO, 2016). Segundo estimativas da Organização Mundial da Saúde de 2018, sete das doenças infecciosas mais fatais do mundo matariam aproximadamente 10,1 milhões de pessoas ao ano, estando em primeiro lugar as gripes e pneumonias, as quais poderiam ser evitadas todos os dias a partir de políticas públicas de segurança e saúde.

As gripes e pneumonias provindas de vírus e bactérias são a grande preocupação de infectologistas e epidemiologistas, diante o alto número de mortes em um período curto de tempo, podendo passar facilmente de uma epidemia para pandemia, ou seja, o número de casos de uma determinada doença, excede claramente a incidência prevista, em um período de tempo determinado, podendo expandir-se por todo o mundo. De acordo com Wallace 
(2016) em sua obra "Big Farms make big flu" traduzindo para o português "Grandes fazendas produzem grandes gripes" destaca que o aumento da ocorrência de vírus no planeta terra, está intimamente relacionado à produção agropecuária e à lucratividade das empresas multinacionais. Segundo o autor, o modo de produção agropecuarista e de agronegócio, lidera a corrida para apropriação e desapropriação de terras, além do desmatamento das últimas florestas primárias em todo o mundo. A devastação das matas para implementação de cultura extensiva e pecuária, faz com que patógenos previamente isolados e controlados por ecologias florestais de longa data se espalhem ameaçando o mundo inteiro (WALLACE, 2016).

Wallace (2016) ainda chama atenção as necessidades de mudanças na produção de alimentos para a saúde pública, a qual deve vir em primeiro plano. A expansão das monoculturas e da pecuária eliminam os sistemas imunológicos e as defesas disponíveis para diminuir a transmissão, sendo necessário, portanto, curar as falhas metabólicas que separam nossas ecologias de nossas economias.

Berbault (2011) traz uma reflexão acerca da criação de "ruminantes" e aves domésticas próximas as áreas urbanas, as quais causam consequências a qualidade de vida, saúde e ambiente, uma vez que estas criações poluem o lençol freático e podem servir de "bombas" na propagação de patógenos nocivos a humanos e aos próprios animais.

Desde o século XIX tem-se destacado patologias ligadas à corona vírus. Este é o nome popular dos vírus da família Coronaviridae, a qual possui sete espécies identificadas até o momento, sendo três destas classificadas como provedoras de doenças graves, também conhecidas como "Síndrome Respiratória Aguda Severa" (Sars-cov-2/Covid 19), com surto no sudoeste da China iniciado em dezembro de 2019; Sars-cov-1 agente da pandemia da Sars com surto na Ásia Continental, entre os anos de 2002-2003; o Mers-cov, causador da Mers no ano de 2012, com surto na Arábia Saudita. As outras 
quatro espécies de coronavírus HKU1, NL63, OC43 e 229E estão associados a doenças com sintomatologia leve.

De acordo com Stefans et al. (2009), os primeiros casos isolados dos Coronavírus não são recentes, estes foram registrados em 1930 como vírus da bronquite infecciosa, e o vírus da hepatite de camundongo e o da gastroenterite de porcos teve registros no ano 1940, ambos apresentam organização similar genômica e estratégia de replicação. Os Coronavírus foram divididos em três grupos sorológicos, I e o II tem sido isolados em mamíferos, enquanto o III, em aves. O sorogrupo II é representado pelos protótipos HCoV-229E e HCoV-NL63, dentre outros, e o Grupo III é representado pelos protótipos MHV, OC43, HKU1 e Sars-Cov (STEFANS et al. 2009). $\quad$ O que se observa de comum nos três tipos de coronavírus infecciosos, é que estes possuem similaridade na origem da doença, tendo seus vírus transmitidos por animais (Figura 01). No caso do Mers, pesquisas indicam que o foco da infecção se deu por camelos (Zaki et al., 2012); do Sars-cov-1 indica-se que morcegos foram a fonte transmissora da infecção (Bell et al., 2004) e o Sars-Cov-2, indica-se também que foram por morcegos (Chan et al., 2020) pela maior proximidade genética, o qual será melhor explicado mais à frente. Os vírus nos animais primários, ou seja, descendentes do vírus não os causam mal, havendo uma relação harmônica com estes microrganismos, o problema começa quando o vírus encontra um novo hospedeiro, causando reações no organismo de sua nova "vitima", que com o tempo pode vir a tornar-se ainda mais nocivo, sendo um dos motivos que se leva a considerar os vírus "armas biológicas". Vale destacar que animais silvestres são vendidos em todo o mundo, e a maioria das vezes esse comércio ocorre de forma ilegal e depredadora, como também acontece no Brasil, representando uma das grandes interferências do homem sobre o ciclo biológico destes animais e respectivamente dos ambientes em que vivem, levando a extinção e a perda de habitat de muitas espécies. 
Figura 1 - Epidemias recentes da família do coronavírus

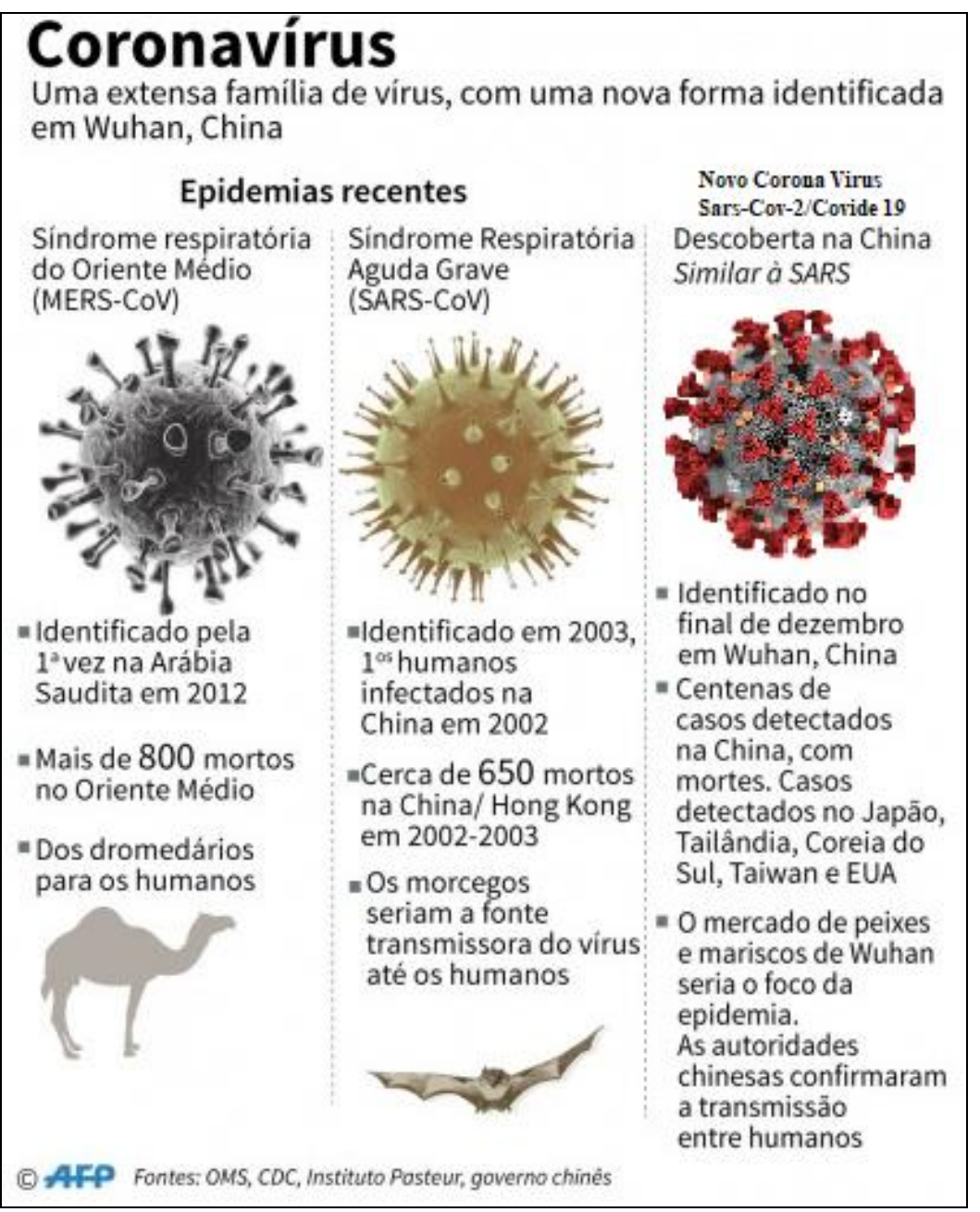

Fonte: modificado de https://checamos.afp.com/o-coronavirus-que-afeta-china-nao-foi-criado-pelos-euapatente-citada-como-prova-e-para-tipo - Acesso em 24/05/2020

Dados de 2019 da Plataforma Intergovernamental sobre Biodiversidade e Serviços Ecossistêmicos (IPBES - Intergovernmental Science Policy Platform on Biodiversity and Ecosystem Services) destacam que as atividades humanas como desmatamento e fragmentação de habitats estão intensificando o surgimento de doenças infecciosas emergentes da vida selvagem.

A cobertura vegetal dos trópicos tem sido destruída para sustentar essa dieta crescentemente carnívora, não apenas na China, mas em vários países do mundo e particularmente entre nós. No Brasil, a remoção de mais de 1,8 milhão de $\mathrm{km}^{2}$ da cobertura vegetal da Amazônia e do Cerrado nos últimos cinquenta anos, para converter suas magníficas 
paisagens naturais em zonas fornecedoras de carne e ração animal, em escala nacional e global, representa o mais fulminante ecocídio jamais perpetrado pela espécie humana (MARQUES, 2020).

Os dados alertam para a ocorrência de cerca 1,7 milhão de vírus não identificados em mamíferos e aves aquáticas e que possuem potencial para infectar pessoas, podendo ser esses a causa de futura crises globais, potencialmente mais perturbadoras e letais do que o COVID-19, que é a atual pandemia vivenciada.

Atualmente o IPBES está organizando três avaliações com relevância direta para a crise atual e o futuro das pandemias, sendo elas: avaliação do uso sustentável de espécies selvagens; avaliação sobre espécies exóticas invasoras e avaliação de diferentes maneiras de entender os valores plurais da natureza. Ainda trabalhos temáticos como biodiversidade, água, alimentos e saúde no contexto das mudanças climáticas são os focos centrais dos estudos, a fim de contribuir na construção de políticas públicas voltadas a conservação ambiental.

Em entrevista para a BBC, a professora Diana Bell, da University of East Anglia, no Reino Unido, afirma que precisamos evitar que novas epidemias ocorram, segundo ela "estamos reunindo animais de diferentes países, habitats distintos, estilos de vida diversos, em matéria de animais aquáticos, animais arbóreos, etc., e estamos misturamos eles em uma espécie de caldeirão", caso essas ações continuam ocorrem nosso futuro será trágico. Em uma pesquisa publicada após o surto do Sars em 2004, a autora já alertava:

"As raízes subjacentes das doenças zoonóticas emergentes podem estar na crise paralela da biodiversidade da perda maciça de espécies como resultado da exploração excessiva de populações de animais selvagens e da destruição de seus habitats naturais pelo aumento da população humana. Lidar com essas duas ameaças ao futuro a longo prazo da biodiversidade, incluindo o homem, requer uma abordagem menos antropocêntrica e mais interdisciplinar dos problemas que exigem a experiência combinada de pesquisa de ecologistas, biólogos da conservação, veterinários, epidemiologistas, virologistas e profissionais da saúde humana (Bell et al, 2004, p. 1107). 
De acordo com Miller e Spoolman (2016) uma das razões pelas quais as doenças infecciosas ainda são uma grave ameaça é que muitas bactérias portadoras de doenças desenvolveram imunidade genética aos antibióticos amplamente utilizados. Além disso, várias espécies de insetos transmissores de doenças, como os mosquitos, tornaram-se imunes aos pesticidas mais usados, como o DDT, que já chegaram a controlar suas populações.

Além disso, o crescimento populacional, a urbanização e as viagens aéreas têm aumentado muito o contato interpessoal, espalhando os microrganismos ainda mais rápido. De acordo Zlojutro et al. (2019) a incerteza substancial em torno do surgimento de novos vírus, especificamente de onde eles vêm e como se espalharão, exige políticas robustas e quantificáveis de controle de surtos validadas que possam ser implementadas em tempo real. As mudanças de comportamento frente ao ambiente afim de reverter os problemas por nos gerados além da restauração de terras degradadas é uma prioridade urgente para proteger a biodiversidade e os serviços ecossistêmicos vitais para toda a vida na Terra afim de garantir o bem-estar humano.

\section{EPIDEMIA SARS-COV-E E AS REFLEXÕES BIOGEOGRÁFICAS}

No intuito de envolver a Biogeografia para dialogar acerca do entendimento da Pandemia do Sars-Cov-2, foram traçados alguns caminhos que englobam reflexões em torno da origem, a dispersão e a distribuição do vírus no globo. Não há uma discussão da patologia em si, mas a relação de sua manifestação e abrangência global progressiva, alterando de um surto local, na cidade Chinesa de Wuhan, para um caráter pandêmico. Cabe destacar que em apenas 3 meses, a Covid-19 atingiu 185 países, diferente do que sabemos das grandes pandemias ocorridas em séculos passados, as quais tinham escala temporal de anos e décadas de dispersão e distribuição entre as diferentes regiões do planeta, como a Peste Bubônica do século XIII ou mesmo a Gripe Espanhola, já no século XX (ALMEIDA, 2009; REZENDE, 2014). 
O que o Sars-Cov-2 difere? A forma de organização e evolução tecnológica da sociedade ao longo dos anos, principalmente nos meios de transporte que intensificaram a conectividade espacial e a Globalização. Na Figura 02 pode-se identificar dois momentos de conectividade entre as regiões e o globo. Primeiro, rotas de especiarias que perduram até a expansão marítima do século $X V$, responsáveis pela conexão e condução de patologias entre as regiões, em especial a Peste Bubônica que dizimou 1/3 da população europeia da época (próximo a 200 milhões de pessoas mortas como destaca REZENDE, 2014). E o segundo, os atuais fluxos aeroviários do século XXI, que instantaneamente conectam pessoas e patologias, como o atual cenário de Pandemia do Sars-Cov-2. Outro fator, para além do aspecto da evolução tecnologia está na relação depredatória e desequilibrada entre sociedade e natureza, podendo ampliar a ocorrência de surtos, epidemias e pandemias, como afirmam UJVARI (2012); DIAMOND (2013) e WALLACE (2016).

Figura 2 - Fluxos de Transportes no século XIII e XXI
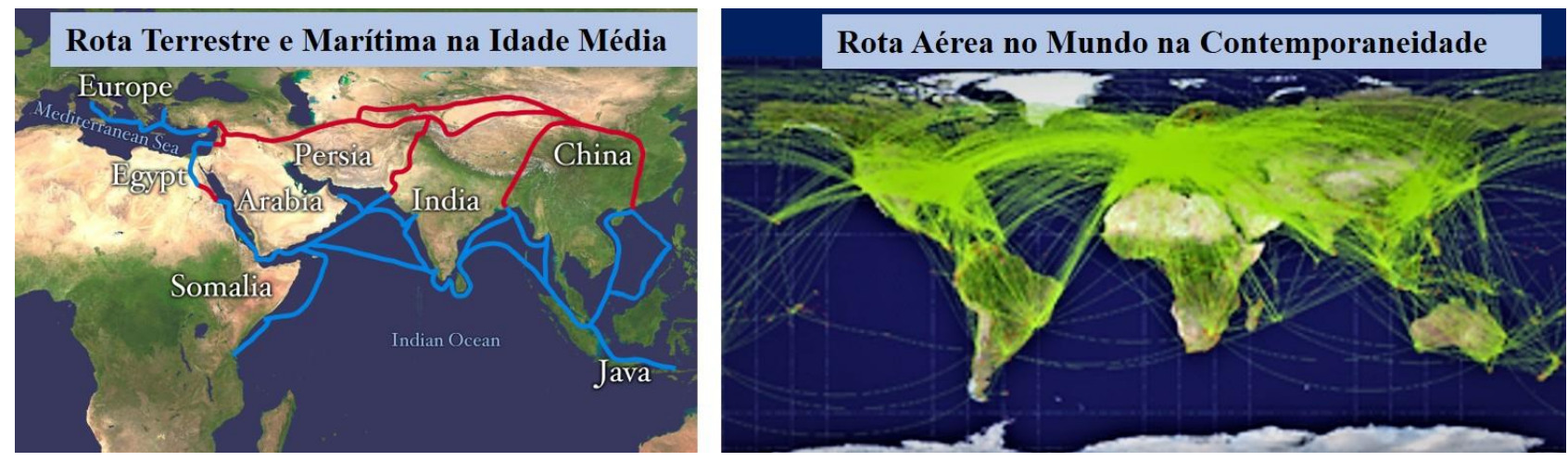

Fonte: Adaptado de https://www.theeagleview.com.br/2019/08/contexto-geopolitico-do-brasil-e.html e https://historiativanet.files.wordpress.com/2013/03/as-grandes-navegac3a7c3b5es-e-a-descoberta-daamc3a9rica.pdf. Acesso em 24/05/2020

Neste cenário de depredação e regressão funcional dos ecossistemas, que se manifesta pelo contato e alastramento de Sars-Cov-2 tomando proporções globais. Embora estejamos vivendo um momento de muitas investigações e campo inconclusivo para origem precisa da Sars-Cov-2 e eclosão desta patologia, estudos apontam a origem para o morcego e outro intermediário, como o pangolim (LAM et 
al., 2020; LI X, et al., 2020) e o rato de bambu (Rhizomys sinensis), como possíveis hospedeiros e a passagem do vírus com mutações para um principal hospedeiro, o homem. Este contato seria feito pelo confinamento de animais silvestres distintos em mercados e feiras asiáticas voltada ao comércio alimentício, expondo os animais a níveis elevados de contato e stress como aponta Chan et al. (2020) nos estudos que testaram intermediários.

O morcego-de-ferradura-grande (Rhinolophus ferrumequinum), identificado como um possível como transmissor primário do vírus, segundo Lam et al. (2020) é um mamífero voador, que se distribui pela Ásia Central (especialmente na China), Oriente Médio e Europa Mediterrânea, é caçado para a venda e consumo de sua carne nos mercados de animais na China. Os morcegos são perigosos para o consumo humano pois possuem tolerância a vírus, sendo hospedeiro de inúmeros deles que podem ser nocivos para outros animais e humanos.

Não apenas o Sars-Cov-2 tem origem associada aos morcegos (ZHOU et al. 2010) como também já mencionados, o SARS-Cov-1 de 2002 a 2004 e o Mers-Cov de 2012. No início de dezembro de 2019, aproximadamente 50 pessoas em Wuhan (cidade chinesa) indicaram o surto a partir de sintomas de pneumonia, base do que viria ser chamada inicialmente de Covid-19, definido em fevereiro de 2020 pela Organização Mundial de Saúde como Sars-Cov-2 (OMS, 2020).

O fluído pulmonar analisado nos chineses continha carga viral similar a presente em morcegos. A maioria destes afetados tinham indícios de contato com o mercado atacadista de animais silvestres de Wuhan. Porém, outros não, o que abriu a hipótese de um hospedeiro intermediário como o pangolim (Manis pentadactyla), o qual apresentava similaridade de $85,5 \%$ a 92\% com o genoma do Sars-Cov-2 (LU et al., 2020), além do o rato de bambu (Rhizomys sinensis) criado em cativeiro e vendido para consumo alimentar e até as civetas (Paradoxurus hermafrodito), animal explorado para seleção de grãos de café na Ásia (GRUBER, 2020).

Para proliferação e caráter patógeno dessa pandemia, seria necessário um hospedeiro intermediário numeroso, que tivesse uma proteína (ACE2) semelhante a 
humana, sintetizasse o Sars-Cov-2 a um vírus potencialmente patógeno à humanos. Hipóteses ainda buscam a chave principal deste hospedeiro, com apontamentos mais voltados no momento para os ratos bambu (Rhizomys sinensis) que são criados em grandes fazendas e capturados em seus habitats. Isto pode ser entendido na seguinte passagem:

O genoma do Sars-CoV-2 apresenta 96\% de similaridade com o do vírus RaTG13, obtido do morcego Rhinolophus affinis, valor bastante superior à similaridade observada com vírus de pangolins, o que sugere que o pangolim não tenha transmitido o vírus diretamente ao homem. O RBD do SARS-CoV-2 é capaz de aderir com alta afinidade no receptor ACE2 humano, mas, dos seis resíduos de aminoácidos identificados como essenciais para a ligação, somente um é compartilhado com o Sars-CoV, causador da Sars, ou com o RaTG13. Isso indica que o SarsCoV-2 desenvolveu através da seleção natural um novo sítio otimizado para a interação com o receptor humano (GRUBER, 2020, p. 02).

Assim, os desequilíbrios nas ações, apropriações e relações do homem na natureza pode ser o ponto de origem da pandemia, não tendo os animais como vilões, mas fruto de ações antrópicas que geraram consequências nocivas, principalmente ao próprio homem, que se transforma o principal hospedeiro do vírus Sars-Cov-2 e disseminador do mesmo mundo.

Não era de se esperar que nos centros urbanos a propagação ganharia destaque, diante as aglomerações típicas das altas densidades populacionais. Este fator pode conter um compendio de varáveis para se analisar os principais surtos, epidemias e agora pandemias provocadas por microrganismos (vírus e bactérias em especial) crescentes após a década de 1970.

A dispersão da patologia Sars-Cov-2 foi auxiliada pela dinâmica de fluxos de pessoas e mercadorias, discutida na figura 2, o que demostra claramente o intenso tráfego aéreo e a conectividade global. Desde a descoberta da doença em dezembro de 2019, na China, até a presente data, 28 de maio de 2020, a trajetória do Coronavírus não seguiu um caminho contínuo, sequencial típico do deslocamento terrestre ou marítimo. Fator que possibilitou reflexões acerca de determinados padrões de distribuição espacial. Três fases de disseminação viral são apresentadas, a 
primeira compreende intervalo temporal de dados de 31 de janeiro a 29 de fevereiro de 2020, que demostra o ponto de origem vinculado ao território Chinês, com dispersões iniciais para novos territórios. A segunda, de 31 de março a 30 de abril, fase de expansão para além da China e criação de diferentes "epicentros", onde a doença vai se distribuir regionalmente (Ásia) e globalmente. E por fim, o mês de maio de 2020 com fechamento no dia 28, o qual atinge caráter pandêmico com distribuídos epicentros e alterações no processo de progressão da própria contaminação. A América, no terceiro momento, passa a ser o principal foco de dispersão e de número de mortes, tornando Estados Unidos e Brasil os "epicentros" virais.

A figura 03 demostra o dia inicial e o final da primeira fase, considerada a origem. Compreende o dia 31 de janeiro e 29 de fevereiro de 2020, evidenciando o foco da doença ainda na China Continental. Em 31 de Janeiro, confirmava-se 262 casos de Sars-Cov-2 saltando para 9826 em menos de um mês, a data final para este recorte.

Figura 3 - Primeira fase de origem e transmissão da Sars-Cov-2
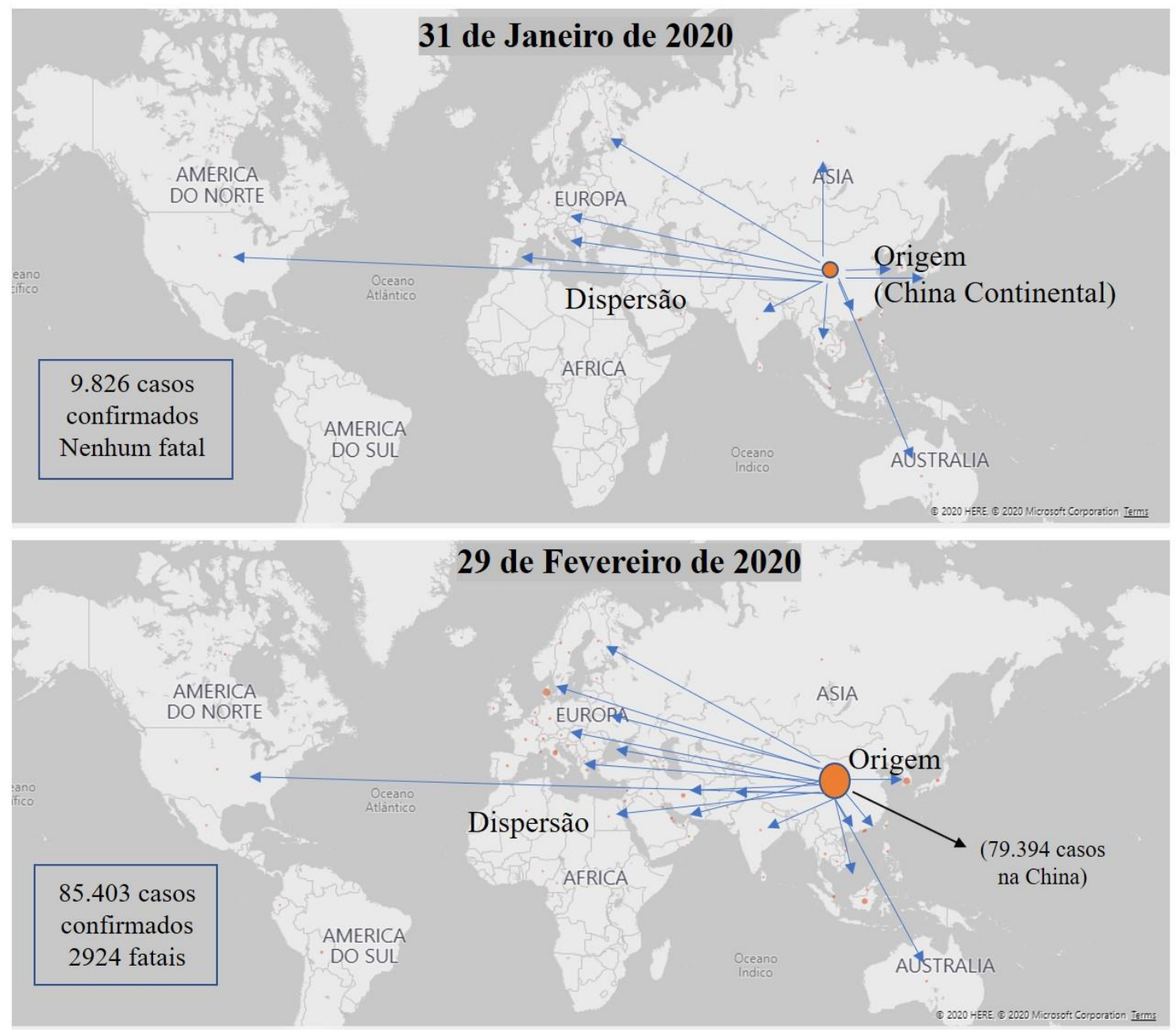
Fonte: Adaptado de https://www.bing.com/covid_Legenda: Centro de Origem (China) e dispersão inicial da Covid-19 para diferentes regiões do planeta em dois momentos, 31 de janeiro e 29 de fevereiro de 2020

Como pode ser visto, a alta transmissão somado as aglomerações típicas do modo de vida urbana e ainda a impossibilidade de as equipes de saúde lidarem com uma nova patologia, contribuíram para a dispersão inicial na China Continental, Sul e Sudeste Asiático, Japão e depois Oceania.

Simultaneamente, casos isolados foram notificados na Europa, Oriente Médio e Estados no final do mês de janeiro, porém sem a criação de epicentros ou centros de dispersão da doença para outras regiões e continentes. O foco estava centrado ainda na Ásia. No final de fevereiro a China atingiu 79.394 casos confirmados do total de 85.403, ou seja, do início da pandemia até 29 de fevereiro, a China sozinha possuía 92\% aproximadamente dos casos confirmados no mundo, gerando 2000 vítimas fatais. Na segunda fase, figura 04, sequencialmente em 31 de março e 30 de abril de 2020, compreendendo dados destes intervalos iniciais e finais, nota-se aumento exponencial do número de afetados pela doença, não tendo mais a China como ponto central ou de origem da dispersão. No início de março, a pandemia é decretada pela Organização Mundial de Saúde. No dia 31 de março registra-se 856.955 casos, ou seja, 10 vezes maior que há um mês (fevereiro) e perto de 20 vezes o número de óbitos, ou seja, 42.089 .

Assim, um novo "epicentro" se configura, a Europa torna-se principal centro de dispersão, justificada pela integração dos países no Bloco Europeu, alta circulação terrestre entre os países na malha ferroviária diária e conectividade com diferentes países fora do território europeu, pelo tráfego aéreo. A entrada no Brasil se fez pelo deslocamento de turistas brasileiros e não brasileiros vindo da Europa, reafirmando o papel da Europa como centro dispersor.

Observando este novo centro dispersor, é possível identificar que os principais países dispersores são os Ocidentais, ou seja, a Alemanha, Itália, França, Espanha e Reino Unido, os quais totalizaram nos dados de 31 de março de 2020, mais de 300 mil casos. Nesse período a China começa a colher resultados do controle da transmissão com medidas rígidas de isolamento populacional (lockdown), como destaca Chen et 
al. (2020) e mesmo sendo centro de origem, entra em estado de equilíbrio para o contágio.

Figura 4 - Fase 2: Dispersão para além da China e Novos Epicentros

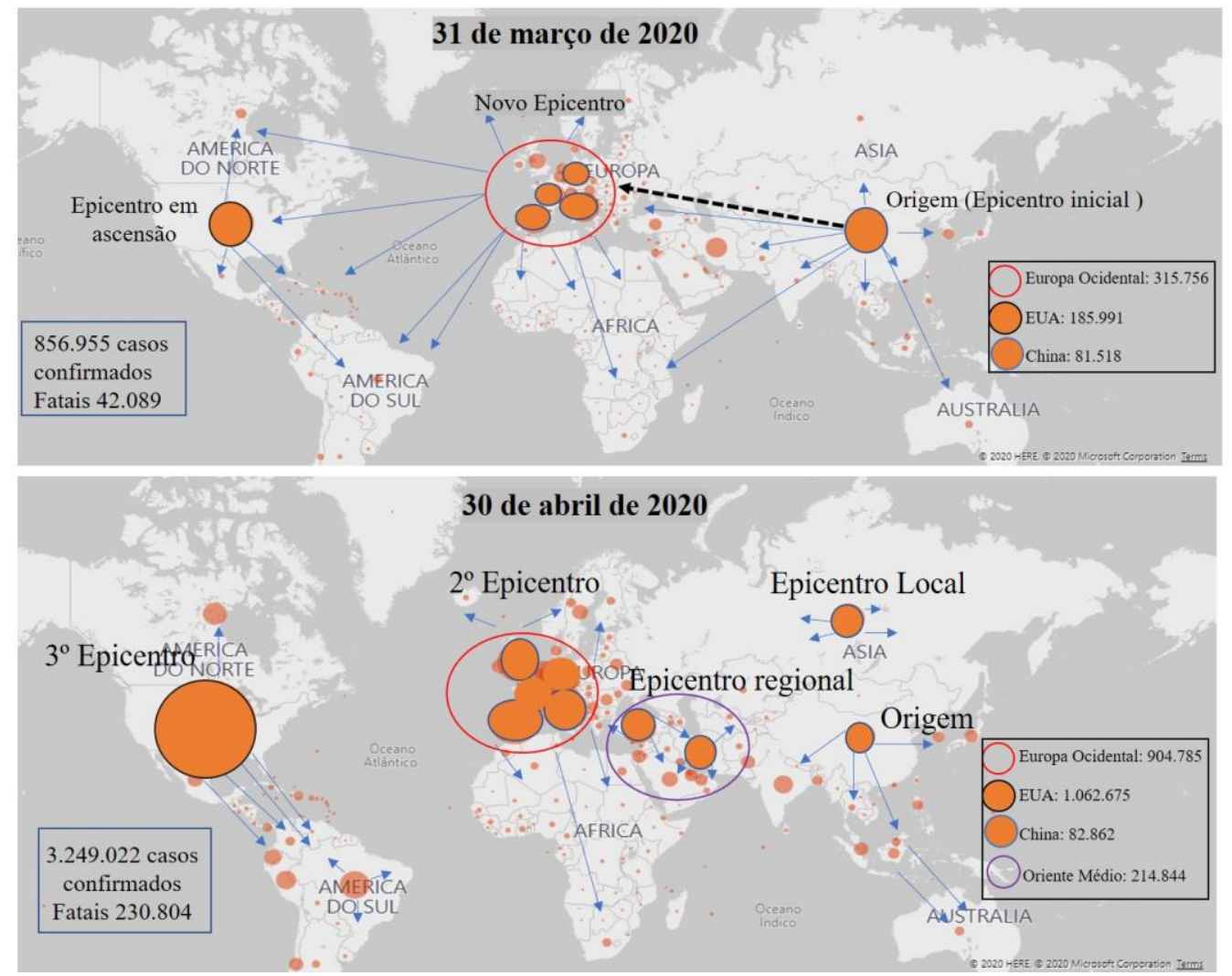

Fonte: Adaptado de https://www.bing.com/covid

Legenda: Centro de Origem (China) e dispersão inicial da Covid-19 para diferentes regiões do planeta em dois momentos, 31 de março e 30 de abril de 2020.

Em 30 de abril de 2020 o mapa sofre mudanças, os Estados Unidos tornam-se um $3^{\circ}$ epicentro da doença, depois da China e Europa e outros epicentros regionais começam a despontar, como no Oriente Média e Rússia. O tempo e espaço na atual conjuntura de Globalização fazem com que a pandemia ganhe um caráter instantâneo. No entanto, quando se analisa a dispersão e distribuição pelos continentes, observa-se este pequeno intervalo entre uma região e outra, permitindo a geração desta nomenclatura de epicentros. Este fato é observado em outras pandemias da História, como a Gripe Espanhola no século XX, com o diferencial o tempo de deslocamento pelo tipo de transporte na época, especialmente o marítimo.

Na figura 3 observou-se que a China tinha em 31 de janeiro representativa de 92\% dos casos confirmados no mundo e em 30 de abril (apenas dois meses depois) o 
centro de origem passa a representar $2,5 \%$ dos casos e os outros epicentros, como EUA margeiam 32\%, Europa Ocidental atinge 27\% e Oriente Médio, em ascensão, $6,6 \%$ dos casos, como destacado na figura 4. A distribuição mundial altera a dinâmica de dispersão e a mesma passa a ser regional, devido a contenção dos fluxos aéreos para o isolamento social. Os epicentros passam a dispersar interno e preferencialmente por via terrestre.

Por fim, observando a Figura 05, percebe-se o caráter pandêmico da dispersão e distribuição global com tendências as oscilações na ordem intercontinental. Relacionando o percentual de casos confirmados nos epicentros 01 a 04 e ainda Rússia e Brasil, destacados na legenda da figura. Observa-se que EUA possui 29,67\% seguido de Europa com 16,9\%, Oriente Médio com Índia, 9,35\%, Rússia com 6,5\%, Brasil 7,24\% e por fim, a China, centro de origem com 1,4\%. A América passa a ser o novo centro de distribuição, tendo EUA e o Brasil como novos epicentros em ascensão, havendo o maior número absoluto de casos no mundo.

Figura 5 - Fase 3: Caráter Pandêmico

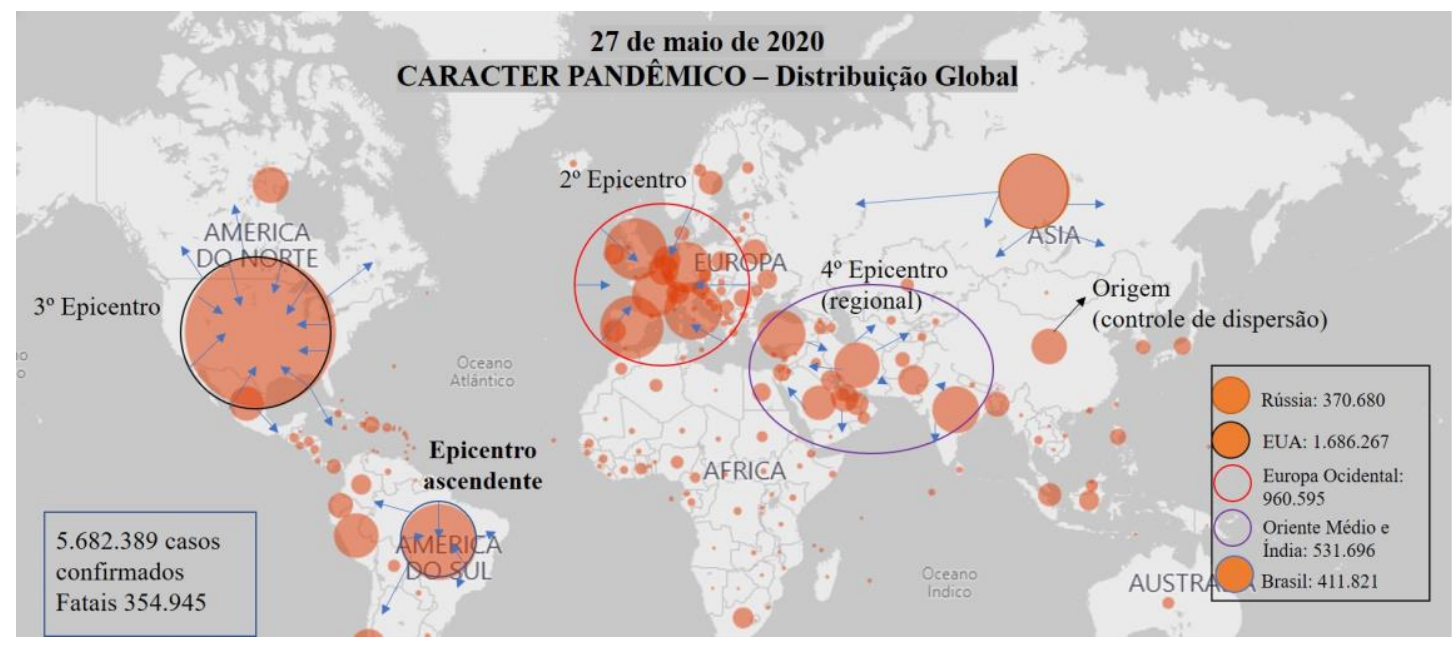

Fonte: Adaptado de https://www.bing.com/covid

Legenda: Caráter Pandêmico com distribuição Global da Covid-19 e outros centros de dispersão e distribuição da doença

A partir da Pandemia consolidada, tem-se a Globalização do Vírus. O tempo e espaço foram realmente encurtados quando se aplica o olhar na propagação de um microrganismo invisível aos nossos olhos, mas que circulante através de seu hospedeiro, o homem, e como qualquer outra espécie do planeta, busca a evolução e 
manutenção no planeta. O controle desta pandemia está na geração de vacinas ou anticorpos que podem regularizar a relação do hospedeiro com o agente, evitando a geração da patologia.

O homem passa a abrigar mais um vírus, deixando-o latente como tantos outros, cabendo-nos refletir diretrizes futuras a segurança e saúde humana, bem como da biodiversidade como um todo. Será que não viveremos a era dos microrganismos? Como podemos interpretar as severas mudanças nos ecossistemas e a relação desequilibrada do homem e natureza a partir do crescimento dos microrganismos? Pode a Biogeografia contribuir para uma era viral englobando este microrganismo na dinâmica de distribuição espacial dos seres vivos? Ou na própria contribuição para o seu entendimento? Uma pandemia pode alterar a trajetória da sociedade, a economia, a política e novos poderes mundiais? Estamos vivendo uma ruptura epidemiológica onde os olhares fixam na redução dos danos à saúde física, emocional e psicológica dos humanos. Novos ou outros paradigmas podem surgir e por que não uma "Biogeografia dos Vírus"?

\section{CONSIDERAÇÕES FINAIS}

Diante os avanços das epidemias e pandemias, que podem se tornar constantes, acreditamos que a biogeografia necessita se debruçar sobre os estudos de microrganismos tomando como base as relações dicotômicas entre sociedade e natureza. A ciência biogeográfica pode estabelecer um elo entre as ciências sociais e naturais ou da terra, oferecendo diálogo entre as ações antrópicas de transformação e construção de paisagens, as quais podem acarretar desequilíbrios, potencializando recorrentes cenas como o presente estudo demostrou, a pandemia do Sars-Cov-2.

Por outro lado, é necessário se pensar no homem como hospedeiro ao longo da história da humanidade, colocando-o como agente de alteração da natureza, incluso a biocenose. Isto reafirma a ligação entre o avanço de diferentes patologias paralelo a história da evolução tecnológica da sociedade. 
Assim, são muitas as contribuições que a Ciência Biogeográfica pode oferecer, principalmente no entendimento dos padrões e na distribuição de patógenos, a partir de uma interpretação geossistêmica dos complexos patogênicos e tecno patogênicos. De tal modo, os patógenos passam a ser analisados a partir da natureza dos lugares, do meio vivo e do meio social, num sistema sócio ecológico dinâmico, o qual é adaptável aos avanços técnicos científicos informacionais, muito discutidos pela geografia crítica. A reflexão biogeográfica para o Sars-Cov-2 é alavancada pelo olhar de duas geógrafas, que buscam através da Biogeografia não só compreender a dinâmica viral (origem, dispersão e distribuição) mas também refletir sobre a importância de uma geografia não dicotômica, já que os vírus como parte da natureza modificam ou eliminam a vida humana, sendo somente a Ciência, com apoio da sociedade e poder público frear a guerra do invisível, já que desconhecemos o nosso futuro.

\section{AGRADECIMENTOS}

Agradecemos ao Grupo de Estudos de Biogeografia e Dinâmica da Paisagem, da Universidade Federal Rural do Rio de Janeiro por impulsionar essa reflexão.

\section{REFERÊNCIAS}

ALMEIDA, M. A. P. As Epidemias nas Notícias em Portugal: cólera, peste, tifo, gripe e varíola, 1854-1918. História, Ciência e Saúde - Manguinhos. Rio de Janeiro; v. 21, n², abri-jun, 2014.

ARAÚJO, A. M. de. Spreading the evolutionary synthesis: Theodosius Dobzhansky and genetics in Brazil. Genetics and molecular biology. Ribeirão Preto, v. 27, n², p. 467-475, 2004.

BALTIMORE, D. Expression of animal vírus genomes. Bacteriological Reviews. v. 35, n³, 1971.

BARBAULT, R. Ecologia Geral: estrutura e funcionamento da biosfera. Petrópolis. Editora Vozes, 2011.

BBC. Coronavírus: a corrida para encontrar o animal que foi origem do surto. Disponível em: https://www.bbc.com/portuguese/internacional-51641776 Acesso em 26/06/2020. 
BELL, D.; ROBERTON, S.; HUNTER, P. H. Animal origins of SARS coronavirus: possible links with the international trade in small carnivores. Phil. Trans. R. Soc. Lond. B (2004) 359, 1107-1114. doi.org/10.1098/rstb.2004.1492

BROWN, J. H.; LOMOLINO, M. V. Biogeografia. 2. ed. Ribeirão Preto, SP: FUNPEC, 2006.

CHAN, J. F. W.; ZHANG, A. J.; YAN, S. Simulation of the clinical and pathological manifestations of Coronavirus disease 2029 (COVID-19) in golden Syrian hamster model: implications for disease pathogenesis and transmissibility. Clinical Infectiouns Diases. Ciaa 325, 2020. Disponível em: https://doi.org/10.1093/cid/ciaa325 Acesso em 25/05/2020.

CHEN, S.; YANG, J.; WHEIZHONG, Y.; CHEN, W. BÄRNIGHAUSEN, T. COVID-19 control in China during mass population moviments at New Year. The Lancet. Vol. 395, n 10226, p. 764-766, 2020. https://doi.org/10.1016/S0140-6736(20)30421-9.

DANSEREAU, P. Biogeography: an ecological perspective. New York: Ronald Press Company, 1957.

DIAMOND, J. Armas, Germes e Aço: os destinos das sociedades humanas.10 $10^{a}$ ed. Rio de Janeiro: Record. 2008.

FERREIRA, M. U. Epidemiologia e Geografia. O complexo patogênico de Max Sorre. PHYSIS Revista de Saúde Coletiva. Vol. 4, nº 1, 1994.

FREITAS JUNIOR, G. de. O trabalho de campo em biogeografia - Homenagem ao Prof. Dr. Felisberto Cavalheiro (1945-2003). Confins, n¹2, 2011.

FIGUEIRÓ, A. Biogeografia: dinâmicas e transformações da natureza. São Paulo: Oficina de Textos, 2015.

GRUBER, A. Covid-19: O que se sabe sobre a origem da doença. Jorna da USP. 2020. Disponível em https://jornal.usp.br/artigos/covid2-o-que-se-sabe-sobre-a-origem-dadoenca Acesso em: 30/05/2020.

IPBES - Intergovernmental Science-Policy Platform on Biodiversity and Ecosystem Services. Introducing IPBES' 2019 Global Assessment Report on Biodiversity and Ecosystem Services. Disponível em: https://ipbes.net/news/ipbes-global-assessment-preview - Acesso em 18/05/2020>.

KAZ, R. Tempos da peste - Uma biografia improvável. Piauí. Edição 164 | maio_2020. Disponível em: https://piaui.folha.uol.com.br/materia/uma-biografia-improvavel/ acesso em $31 / 05 / 2020$.

LAM, T. T.Y.; SHUM, M. H. H.; ZHU, H. C. "Identifying SARS-CoV-2 related coronaviruses in Malayan pangolins." Nature. (2020). 
LI, X.; WANG, W.; ZHAO, X. "Transmission dynamics and evolutionary history of 2019-nCoV." Journal of Medical Virology. 92(5): 501-511. (2020).

LOCEY, K. J.; LENNON, J. T. Scaling laws predict global microbial diversity. Proceedings of the National Academy of Sciences (PNAS). May 24, 2016113 (21) 5970-5975; first published May 2, 2016. https://doi.org/10.1073/pnas.1521291113

MARQUES, L. A pandemia incide no ano mais importante da história da humanidade. Serão as próximas zoonoses gestadas no Brasil? Ciência, saúde e sociedade: Covid-19, Maio, 2020. Disponível em: https://www.unicamp.br/unicamp/noticias/2020/05/05/pandemia-incide-noano-mais-importante-da-historia-da-humanidade-serao-proximas Acesso em 18/05/2020.

MARQUES NETO, R. Zoogeografia do Brasil: A fauna, a paisagem e as organizações espaciais. Curitiba (PR): Editora CRV- 2018.

MACFARLAN, T.; GIFFORD, W.; DRISCOLL, S.; WESLEY D.; LETTIERI, K.; ROWE, H. M.; BONANOMI, D, FIRTH, A.; SINGER, O. ;TRONO, D. ;PFAFF, S. L. Embryonic stem cell potency fluctuates with endogenous retrovirus activity. Nature. 487, 57-63 (2012). https://doi.org/10.1038/nature11244

MILLER, G. T.; SPOOLMAN, S. E. Ciência Ambiental. Tradução da $14^{\circ}$ edição norte-americana. 2a edição brasileira. Cengage Learning. São Paulo. 2016.

MOORE, J. A. Science as a way of knowing: genetics. Amer. Zool., v. 26, p. 583-747, 1986.

MOREIRA, R. Nossos Clássicos - Max Sorre. GEOgraphia. Ano v, n¹0, 2003.

NASIR, A.; CAETANO-ANOLLÉS, G. A phylogenomic data-driven exploration of viral origins and evolution. Science Advances. Vol. 1, n 8, 2015. DOI: 10.1126/sciadv.1500527

ORGANIZAÇÃO MUNDIAL DE SAÚDE - OMS/WHO. The top 10 causes of death (2018). Disponível em: https://www.who.int/news-room/fact-sheets/detail/the-top-10-causes-of-death Acesso em: 18/05/2020.

ORGANIZAÇÃO MUNDIAL DE SAÚDE - OMS/WHO. OMS declara Pandemia de Covid-19 (2020). Disponível em: https://www.unasus.gov.br/noticia/organizacao-mundial-de-saude-declarapandemia-de-coronavirus Acesso 15/05/2020.

REZENDE, J. M. À Sombra do Plátamo: crônicas da história da medicina (online). São Paulo: Editora Unifesp, 2009. As grandes epidemias da história. p. 77-82.

ROMARIZ, D. A. Biogeografia: temas e conceitos. São Paulo: Scortecci, 2012.

SALZANO, F. M. Genômica e evolução: moléculas, organismos e sociedades. Oficina de textos. São Paulo, 2012.

SANTOS, M. Espaço e método. São Paulo: Nobel, 1997. 
SANTOS, M. Técnica, espaço, tempo: globalização e meio técnico-científico-informacional. São Paulo: Hucitec, 1998.

STEPHENS, P. R. S.; OlIVEIRA, M. B. S. C. de; RIBEIRO, F. C.; CARNEIRO, L. A. D. Virologia. Cap. 2. In: Molinaro, E. M.; Caputo, L. F. G.; Amendoeira, M. R. R. (Org). Conceitos e Métodos para a Formação de Profissionais em Laboratórios de Saúde, v. 4. Rio de Janeiro: EPSJV, IOC, 2009.

TROPPMAIR, H. Biogeografia e meio ambiente. 9. ed. rev., e atual. Rio de Janeiro, RJ: Technical Books, 2012.

UJVARI, S. C. A história da disseminação dos microrganismos. Dossiê epidemias. Estudos avançados. Vol.22, n64. Dec. 2008. https://doi.org/10.1590/S0103-40142008000300011.

UJVARI, S. C. A história da humanidade contada pelos vírus - Bactérias, Parasitas e Outros Microrganismos. Editora Contexto. São Paulo, 2012.

WALLACE, R. Big Farms Make Big Flu - Dispatches On Influenza, Agribusiness, And The Nature Of Science. Monthly review press. NYU Press, 2016.

WHITMAN, W. B.; COLEMAN, D. C.; WIEBE, W. J. Prokaryotes: The unseen majority. Proceedings of the National Academy of Sciences (PNAS). USA Vol. 95, pp. 6578-6583, June 1998. DOI: 10.1073 / pnas.95.12.6578

WHO - World Health Organization. Disease burden and mortality estimates. Disponível em: https://www.who.int/healthinfo/global_burden_disease/estimates/en/index1.html. Acesso em 26/06/2020

ZAKI A. M.; VAN BOHEEMEN. S.; BESTEBROER, T. M.; OSTERHAUS, A. D.; FOUCHIER, R. A. Isolation of a Novel Coronavirus from a Man with Pneumonia in Saudi Arabia. The New England Journal of Medicine. 367:1814-1820, 2012. https://doi.org/10.1056/NEJMoa1211721.

ZHOU, P.; YANG, X.L; WANG, X.G; HU, B.; ZHANG, L. ; ZHANG, W. ; RUI SI, H. ; ZHU, Y. ; LI, B.; LIN, C. H.; CHEN, H. D. ; CHEN, J. ; LUO, Y. ; GUO, H. ; JIANG, R. ; LIU, M. Q. ; CHEN; Y; SHEN, X. R. ; WANG, X. ; ZHENG, X. S. Discovery of a novel coronavirus associated with the recent pneumonia outbreak in humans and its potential bat origin. BioRxiv, 2020.

ZLOJUTRO, A.; REY, D. E.; GARDNER, L. A decision-support framework to optimize border control for global outbreak mitigation. Scientific Reports, 9, 2216 (2019). https://doi.org/10.1038/s41598-019-38665-w>. 